\title{
ROLE OF PURUN TIKUS IN VERTICAL SUBSURFACE FLOW CONSTRUCTED WETLAND IN TREATING MANGANESE (Mn) FROM COAL MINE DRAINAGE
}

\author{
Nopi Stiyati Prihatini ${ }^{1}$, Indah Nirtha ${ }^{1}$, Muhammad Sadiqul Iman ${ }^{1}$ \\ ${ }^{1}$ Environmental Engineering Department, Engineering Faculty, Lambung Mangkurat University, \\ Banjarmasin, South Kalimantan, Indonesia, \\ 1email: ns.prihatini@unlam.ac.id
}

\begin{abstract}
Constructed wetland $(\mathrm{CW})$ is one of the passive methods used to process coal mine drainage. In this study, we used vertical (VF) subsurface flow (SSF) constructed wetland (CW) with purun tikus (Eleocharis dulcis). The purpose of the study was to assess the role of purun tikus in increasing the efficiency of constructed wetland to remove $\mathrm{Mn}$ from Coal Mine Drainage. The constructed wetland operated under batch hydraulic loading regime. The results showed that the efficiency of the VF-SSFCW System without purun tikus was $15.53 \%$ and VF-SSFCW with purun tikus $78.94 \%$.
\end{abstract}

Keywords: coal mine drainage, constructed wetland (CW), Manganese (Mn), purun tikus (E.dulcis)

\section{INTRODUCTION}

Metal-rich water can form on the acid heap of remnants of mining operations, involving chemical and biological reactions. The generic term of acid mine drainage (AMD) is often used to describe the disposal of mine waste water with a $\mathrm{pH}$ above 6 , especially at the point of discharge (in which dissolved oxygen concentrations are often very low). The metals $\mathrm{Fe}$ and $\mathrm{Mn}$ are generally present in reduced forms (Fe2+ and $\mathrm{Mn2+}$ ) on the anoxic AMD. These metal forms are much more stable at higher $\mathrm{pH}$ than other forms of oxidation ( $\mathrm{Fe} 3+$ and $\mathrm{Mn} 4$ $+)$. Some flows of AMD are neutral to alkaline, but most AMD showed a huge decrease in $\mathrm{pH}$ due to the reaction of oxygenates. This is because the total acidity is derived from acidity-proton (i.e, the concentration of $\mathrm{H}+$ ) and acidity-mineral (the combined concentrations of dissolved metals, especially $\mathrm{Fe}, \mathrm{Al}, \mathrm{Mn}$, which produce protons when they undergo hydrolysis).
Acid mine drainage (AMD) causes environmental pollution that affects the location of the mining industry. Precautions for AMD formation or minimizing the AMD migration from its source are carried out to tackle AMD. However, there are situations in which AMD is ultimately collected, processed, and then released into the environment. There is a wide choice of technologies and methods available for the remediation of AMD, which are chemical or biological mechanisms, to neutralize and remove metal from AMD. These abiotic and biological processing systems are classified as the Active Processing (requiring inputs of sustainable resources to sustain the process) or the Passive Processing (requiring inputs of resources relatively few in operation) (Johnson and Hallberg 2002; Coulton, Bullen et al. 2003; Johnson and Hallberg 2003; Hallberg and Johnson 2005).

Constructed wetland can be an alternative way to resolve the AMD. It is one of the passive methods used to process AMD from coal mining. It is developed by dredging the soil to create a shallow pond $(0.3-0.5 \mathrm{~m})$ and building dikes around it so that it is strong enough to accommodate large volume water when it rains at any time. Pitcher water is then released gradually into the constructed wetland, which is subsequently released to public channel. The floras tolerant to acidic environment and high levels of metals are planted at the bottom of the pond, wetland, and dry land along the embankment (Vile and Wieder 1993).

Four kinds of mechanisms affecting the removal of metal in the constructed wetland are: (1) adsorption by fine textured sediment and organic materials, (2) deposition of salt (mainly sulphide and oxyhydroxide), (3) the absorption and transformation of pollutants by plants and bacteria, and (4) the deposition of suspended solids due to the slow rate of flow of waste water (Gambrell 1994; Vymazal 2005; 
Lesage, Rousseau et al. 2007). All these processes lead to the accumulation of pollutants in the substrate metal and constructed wetland. The efficiency of constructed wetland system greatly depends on (i) concentrations and dynamics of metals in waste water and (ii) the hydraulic load that goes to the constructed wetland (Kadlec and Knight 1996; Wood and Shelley 1999; Vymazal 2003).

Many research results have been reported on plants of wetlands and their role in the process of wastewater treatment in constructed wetlands. Metal uptake by plants turned out to play a very diverse role in remediation of metal (Mitsch and Wise 1998; Sobolewski 1999; Fritioff, Kautsky et al. 2005; Fritioff and Greger 2006; Vardanyan and Ingole 2006). Plants can be considered as a metal storage site for a while, i.e during the growing season. It can have a negative impact on water quality during aging in plants (Coats, Pruett et al. 1994). Some species of plants show higher metal concentrations in their dead tissues (Fritioff and Greger 2007). In the decomposition of biomass are a number of metals released back into the environment.

A system of subsurface flow constructed wetlands (SSFCW) with plants and without plants, combined with hydroponic systems (HP), can be used to analyze the removal efficiency of Fe and $\mathrm{Zn}$ from AMD on the condition of long-term field (Wiessner, Kuschk et al. 2006). The maximum removal for $\mathrm{CW}$ system with plants is $94-97 \%\left(116-142 \mathrm{mg}^{-\mathrm{m}^{-2}} \cdot \mathrm{d}^{-1}\right)$ for $\mathrm{Fe}$ and

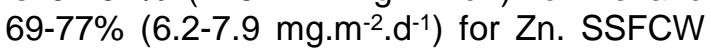
system with the plant turns out to be the most sensitive to high rainfall. The results showed that all types of CW capable of removing $\mathrm{Fe}$ with a maximum rate of approximately 60 $98 \%$. Most $\mathrm{Fe}$ is converted and stored in the sediment at the bottom of $\mathrm{CW}$. The amount absorbed by plants (from 0.03 to $0.3 \%$ ) and the number detained in the gravel substrate $(0.03$ to $1.7 \%)$ of the total input $\mathrm{Fe}$ and $\mathrm{Zn}$ in the influent wastewater. CW response to rainfall showed a remobilization of metals that accumulate in the rhizosphere of plants and the importance of buffering the effects of subsurface flow system. Plants in $\mathrm{CW}$ system is very important in removing the metals from AMD.

Subsurface Flow-Wetland system is one of wastewater treatment systems for constructed wetlands, in which the working principle of wastewater treatment system is by utilizing the symbiosis between water plants and microorganisms in media around the root system (rhizosphere) of the plants. Subsurface Flow-Wetland system have an advantage in terms of cost and environmental friendliness. It can process domestic, agricultural and some of industrial waste including heavy metals; high treatment efficiency (80\%) and lower cost of planning, operation and maintenance, as well as not requiring high skills (Tangahu \& Warmadewanthi in Supradata, 2005).

Subsurface Flow Wetland system is subdivided into two, namely vertical subsurface flow and horizontal subsurface flow. Vertical subsurface flow system was selected for this study. The selection of Vertical Subsurface Flow System was based on Risnawati and Damanhuri' research (2010) stating that the vertical reactor is more effective to set aside the metal $\mathrm{Fe}, \mathrm{Cu}$ and $\mathrm{Zn}$ compared to the horizontal reactor. The working principle of this wastewater treatment system was to utilize the symbiosis between water plants and microorganisms in media around the root system (rhizosphere) of the plants; therefore, the selection of plants became the most important thing in this study.

Purun tikus is one of water plants found in many acid sulfate soils with the types of clay or humus which occupies an open/burnt area (Flach and Rumawas 1996) in South Kalimantan. In general, the land has experienced an acute acidification (Noor 2004). Purun tikus (Eleocharis dulcis) is a weed that grows and develops in muddy, tidal swamps. This plant belongs to the family Cyperaceae. The trunk is cylindrical with a diameter of 2-3 $\mathrm{mm}$, and the height can reach $150 \mathrm{~cm}$, unbranched, leafless and green so that photosynthesis is done through the stem. Flowers are located at the tip of the stem (Indrayati 2011). This plant has many benefits, such as the juice of the tuber containing antibiotic 'puchiin', effective against Staphylococcus aureus, Escherichia coli and aerobacter aerogenes. In addition, this plant serves as a rice pest control component, that is as a trap crop for rice stem borers and food for locusts. Many of white rice stem borers lay their eggs $(>6000)$ on the upper part of the plant stem (Asikin, 2011). 
The purpose of this study was to study the role of purun tikus in increasing the efficiency of constructed wetland in removing Mn from Coal Mine Drainage.

\section{MATERIALS AND METHODS}

The study used vertical (VF) subsurface flow (SSF) constructed wetland $(\mathrm{CW})$, which operated under batch hydraulic loading regime. The dimension of VFSSFCW was $65 \mathrm{~cm} \times 35 \mathrm{~cm} \times 35 \mathrm{~cm}$.

It was conducted at Greenhouse of Lambung Mangkurat University. Acid mine drainage (AMD) was derived from coal mining waste of PT Jorong Barutama Greston, South Kalimantan, Indonesia, that exceeded the Indonesian wastewater standards for coal mining and its activities. The wetland vegetation used in the study is purun tikus (Eleocharis dulcis) with an average height of $15 \mathrm{~cm}$ and a plant spacing of $15 \mathrm{~cm}$. The media were acid sulphate soils, the original habitat of purun tikus with a height of $30 \mathrm{~cm}$ on each model. Media and water samples were tested by testing the parameters of Manganese $(\mathrm{Mn})$ in the laboratory using Atomotic Absorption Spectrophotometer with flame in accordance with the Indonesian Standards for $\mathrm{Mn}$, namely SNI 6989.5:2009.

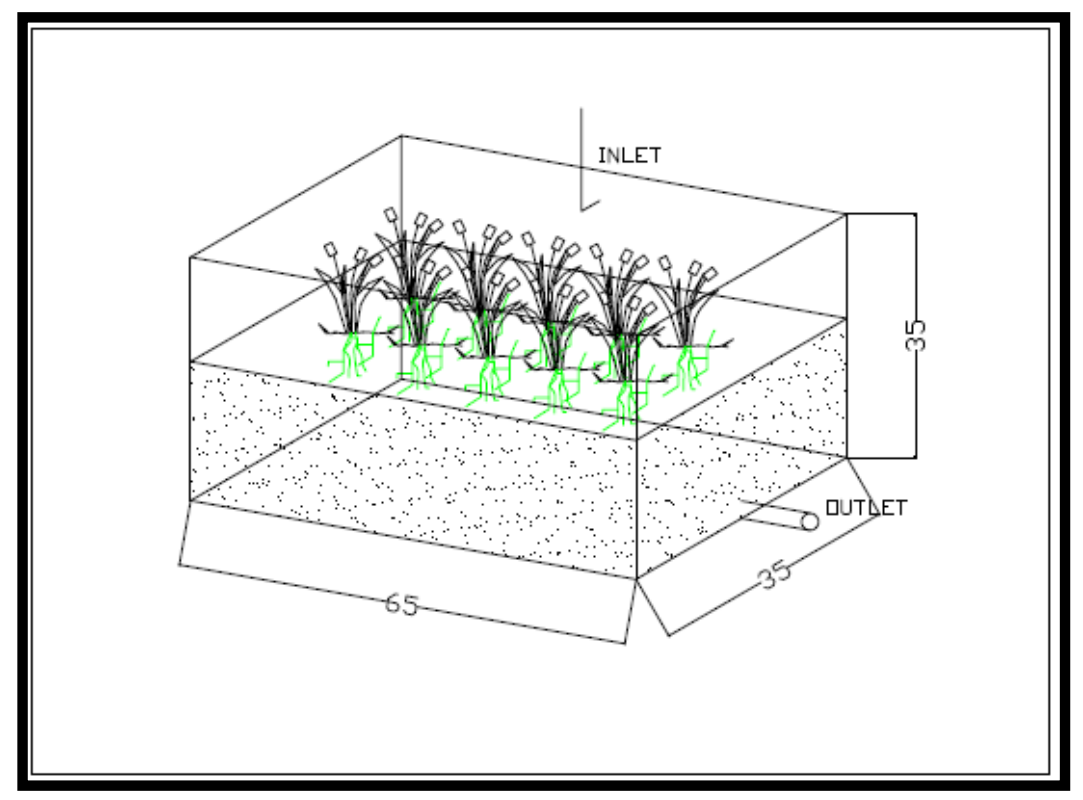

Figure 1.VF SSF CW design

\section{Data analysis}

Data were obtained in the form of $\mathrm{Mn}$ concentration in media VF SSF CW and effluent VF SSFCW. The data are presented in tabular or graphical form in order to reflect the changing of the results of test parameter measurements. The efficiency of VF SSFCW was calculated using the equation:

$$
E=\frac{C_{0}-C_{e}}{C_{0}} \times 100 \%
$$

With:

$$
\begin{array}{ll}
\mathrm{E} & =\text { Efficiency }(\%) \\
\mathrm{C}_{0} & =\text { influent } \mathrm{Mn} \text { concentration }(\mathrm{ppm}) \\
\mathrm{Ce} & =\text { effluent } \mathrm{Mn} \text { concentration }(\mathrm{ppm})
\end{array}
$$

\section{RESULTS AND DISCUSSION}

The result of this study, the concentration of $\mathrm{Mn}$ in media at VF-SSFCW system, is shown in Figure 2, while Figure 3 shows the concentration of $\mathrm{Mn}$ in effluent at VF-SSFCW system. Figure 4 shows $\mathrm{Mn}$ concentration in both media and effluent at VF-SSFCW System for a nine day treatment.

We calculated the efficiency of VFSSFCW System from data at Figure 3. The efficiency of VF-SSFCW without purun tikus was $15.53 \%$ and VF-SSFCW with purun tikus $78.94 \%$. 
Nopi S.Prihatini, Indah Nirtha, Muhammad S.Iman: Role of Purun Tikus in Vertical Subsurface

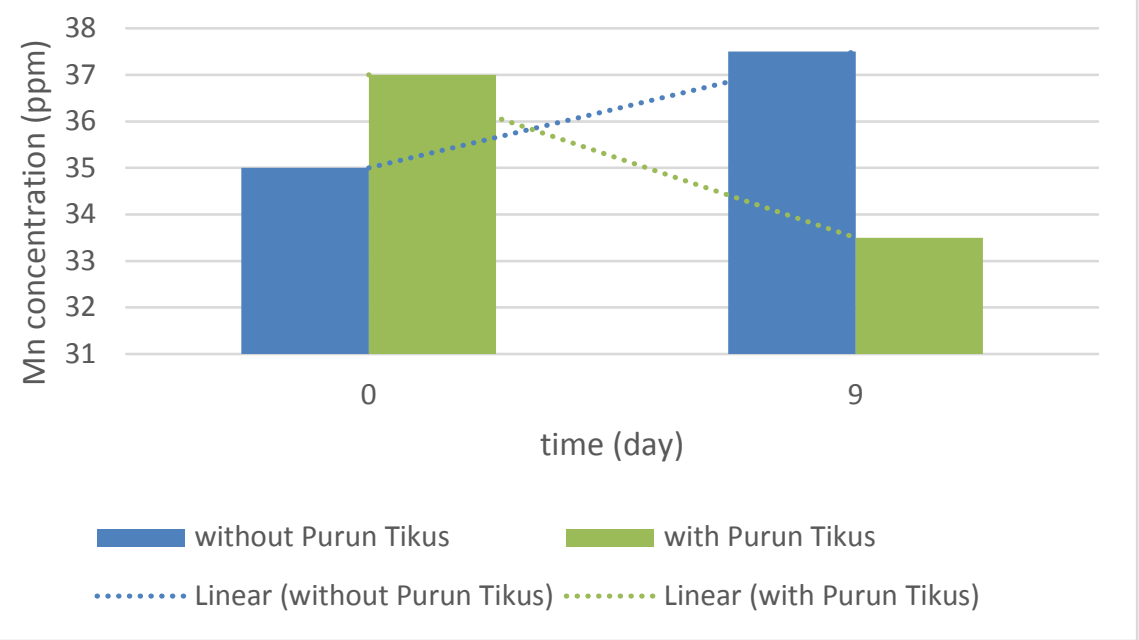

Figure2. Mn concentration in media at VF-SSFCW system

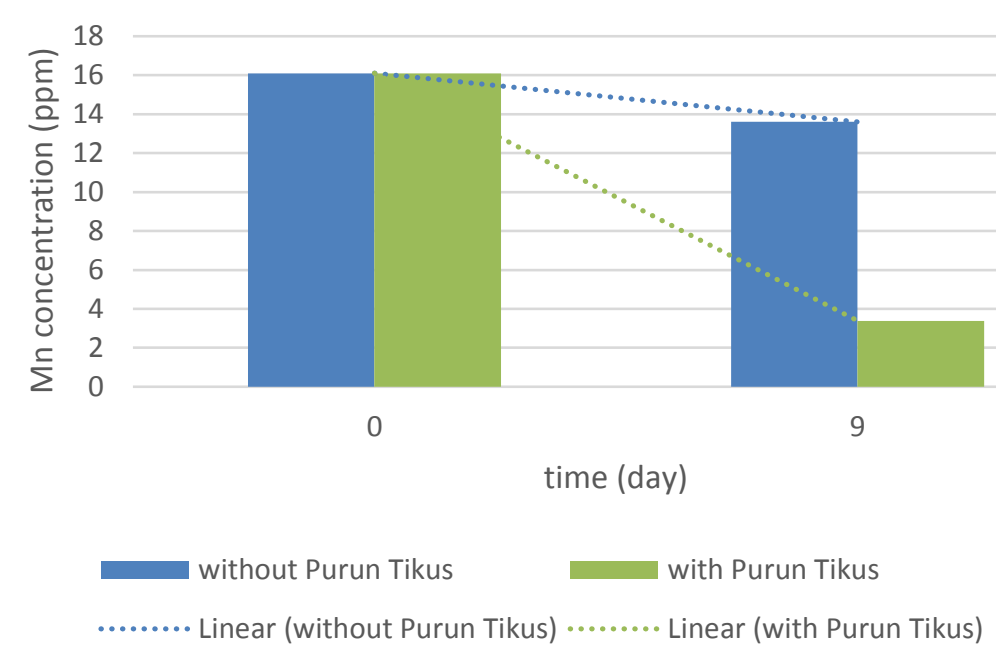

Figure 3. Mn concentration in effluent at VF-SSFCW system

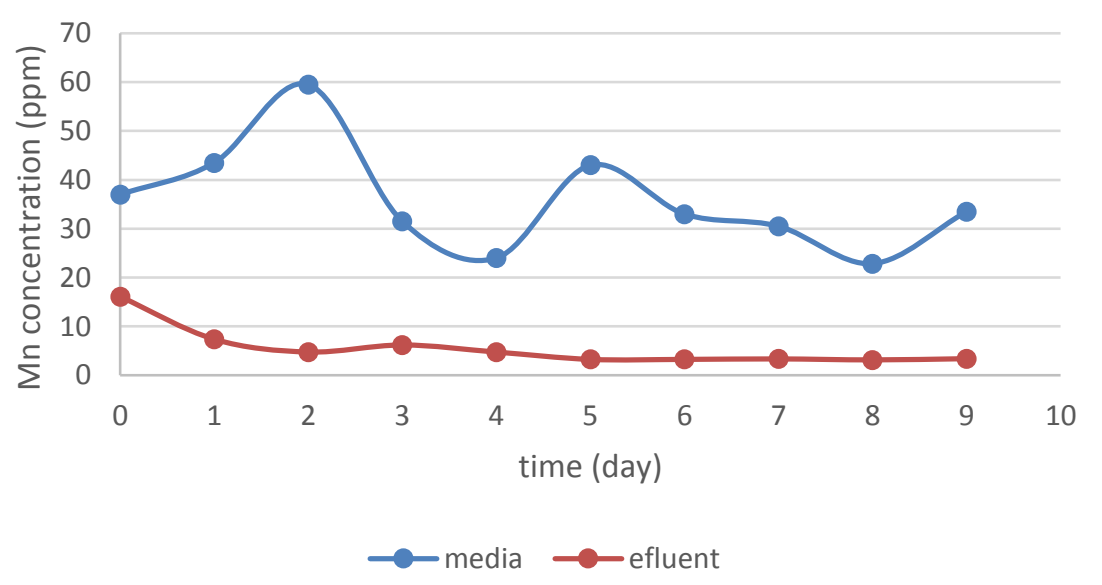

Figure 4. Mn concentration in media and effluent at VF-SSFCW system with purun tikus 
Vertical subsurface flow constructed wetland system consists of essential types of vertical down-flow and up-flow. The vertical flow system used in this study was vertical down-flow that utilized gravity force or downflow. In the vertical down-flow, the water flowed into the constructed wetland of the upper layer of the media and outlet channels made in the bottom of the media, so that the water would flow down to pass through the root zone with the force of gravity. In the system of vertical down-flow, it is expected that there would be a direct contact between the root zone of purun tikus and acid mine drainage from coal mining, so that the decrease in Mn can be achieved. In addition, microorganisms are also expected to play a role in this system. The result of earlier study showed that the Model of Vertical Subsurface Flow Constructed Wetlands with purun tikus capable of removing iron and raising $\mathrm{pH}$ of the acid mine drainage(Prihatini 2015).

The Mn concentration in the media at VF SSF-CW without purun tikus was higher than that at VF SSF-CW with purun tikus. The process of sedimentation supported by the process of filtration in the media resulted in a decrease in pretty high $\mathrm{Mn}$ because the particles in the media formed a filter in holding $\mathrm{Mn}$ metal in the acid mine water from coal mining. Whereas in purun tikus, the filtration process occurred in the root zone where the roots of the plant held metal $\mathrm{Mn}$ contained in the waste water. It is also because the purun tikus' need for metal $\mathrm{Mn}$ as its nutrient is fairly high.

In this study, effluent VF SSF-CW with purun tikus had less concentration of $\mathrm{Mn}$ than the VF SSF-CW without purun tikus. The results of the measurement of $\mathrm{Mn}$ concentration in the media at VF SSF-CW with purun tikus showed fluctuations and experienced the lowest concentration on day 4 and 8. While the Mn concentration in the effluent VF SSF-CW with purun tikus tended to decrease until day 9 . A previous study has suggested that purun tikus can accumulate ferrous metals in its body tissues.

Purun tikus had the highest $\mathrm{Fe}$ concentration on day 6 for VF-SSFCW and day 13 for HF-SSFCW (Prihatini 2015). This shows that purun tikus planted at VF-SSFCW reaches maximum uptake for 6 days and 13 days at HF-SSFCW. After that time span, it is recommended that purun tikus plants should be harvested and replaced. However, further study is needed on the use of purun Tikus plants at CW applied in the field in the long term (Munawar 2007).

Protein transporters such as Citrate effuxer FRDL1 are very important in the process of transporting $\mathrm{Fe}$ along with the transpiration stream to the shoot area of the plant. Fe can also be transported by the phloem tissue towards the tip and the tissue of young plants (Briat and Lobréaux 1997; Samiotakis and Ebbs 2004; Briat 2007; Kim and Guerinot 2007; Jeong and Connolly 2009; Palmer and Guerinot 2009; Solti, Kovács et al. 2012; Yoshida and Negishi 2013).

Risnawati and Damanhuri (2010) used the plant Cyperus papyrus whose family is the same with purun tikus, family Cyperaceae, in HF-SSFCW for 9 days to remove the metal from landfill leachate. When compared with the results of this study, E. dulcis (17800.35 mg) accumulate $\mathrm{Fe}$ was more greater than C. papyrus (2553.01 mg) (Risnawati and Damanhuri 2010). Another study that used E. dulcis in VF-SSFCW with media variation showed that E. dulcis can take up $4263 \mathrm{ppm}$ Fe within 5 days (Prihatini 2015), which makes purun tikus ( $E$. dulcis) have high potential to be used in phytoremediation

\section{CONCLUSION}

Purun tikus (Eleocharis dulcis) planted in Vertical Flow Subsurface Constructed Wetland (VF-SSFCW played an important role at the system and enhanced the system efficiency. The efficiency of VF-SSFCW System without purun tikus was $15.53 \%$ and VF-SSFCW with purun tikus plant $78.94 \%$.

\section{REFERENCES}

Briat, J. F. (2007). "Iron Dynamics in Plants." Advances in Botanical Research 46: 137-180.

Briat, J. F. and S. Lobréaux (1997). "Iron transport and storage in plants." Trends in Plant Science2(5): 187193.

Coats, K. S. C., S. B. Pruett, et al. (1994). "Bovine immunodeficiency virus: incidence of infection in Mississippi dairy cattle." Veterinary Microbiology42: 180-189. 
Coulton, R., C. Bullen, et al. (2003). "The design and optimization of active mine water treatment plants." Land Contam. Reclam.11(3): 273-279.

Flach, M. and F. Rumawas (1996). "Plants Yielding Non-Seed Carbohydrates." Plant Resources of South-East Asia (PROSEA)9: 97-100.

Fritioff, $\AA$. and M. Greger (2006). "Uptake and distribution of $\mathrm{Zn}, \mathrm{Cu}, \mathrm{Cd}$, and $\mathrm{Pb}$ in an aquatic plant Potamogeton natans." Chemosphere63: 220-227.

Fritioff, Å. and M. Greger (2007). "Fate of cadmium in Elodea canadensis." Chemosphere67: 365-375.

Fritioff, Å., L. Kautsky, et al. (2005). "Influence of temperature and salinity on heavy metal uptake by submersed plants." Environmenal Pollution133: 265-274.

Gambrell, R. P. (1994). "Trace and toxic metals in wetlands a review." Journal of Environmental Quality23: 883- 889.

Hallberg, K. B. and D. B. Johnson (2005). "Microbiology of a wetland ecosystem constructed to remediate mine drainage from a heavy metal mine." Sci. Total Environ.338(1-2): 53-66.

Indrayati, L. (2011). "Purun Tikus Potentially Fix Water Quality in Tidal Swamp." Badan Litbang Pertanian Edisi 6-12 April 2011 No. 3400 Tahun XLI.

Jeong, J. and E. L. Connolly (2009). "Iron uptake mechanisms in plants: Functions of the FRO family of ferric reductases." Plant Science176 (6): 709-714.

Johnson, D. B. and K. B. Hallberg (2002). "Pitfalls of passive mine water treatment." Reviews Environ Sci Bio/Technol.1(4): 335-343.

Johnson, D. B. and K. B. Hallberg (2003). "The microbiology of acidic mine waters." Res Microbiol.154(7): 466 $-473$.

Kadlec, R. H. and R. L. Knight (1996). Treatment Wetlands. Boca Raton, Florida, USA, CRC Press, Inc.

Kim, S. A. and M. L. Guerinot (2007). "Mining iron: Iron uptake and transport in plants." FEBS Letters581(12): 2273-2280.

Lesage, E., D. P. L. Rousseau, et al. (2007). "Accumulation of metals in a horizontal subsurface flow constructed wetland treating domestic wastewater in Flanders, Belgium." Science of the Total Environment380: 102 - 115.

Mitsch, W. J. and K. M. Wise (1998). "Water Quality, Fate of Metals, and Predictive Model Validation of Constructed Wetland Treating Acid Mine Drainage." Wat. Res. Vol. , No. 6, pp. , 199832(6): 1888-1900.

Munawar, A. (2007). "Utilization of local biological resources in the passive tretment method of acid mine drainage: Constructed Wetlands." Journal of Soil and Environment Sciences)7(1): 31-42.

Noor, M. (2004). Land Swamp, Nature and Management of Troubled Acid Sulfate Soils. Jakarta, PT Raja Grafindo Persada.

Palmer, C. M. and M. L. Guerinot (2009). "Facing the challenges of $\mathrm{Cu}, \mathrm{Fe}$ and $\mathrm{Zn}$ homeostasis in plants." Nature Chemical Biology5: 333 340.

Prihatini, N. S. (2015). "Iron (Fe) Bioconcentration in Purun Tikus (Eleocharis dulcis) planted on constructed wetland treating Coal Acid Mine drainage " This article was presented at the International Seminar: "Forest Rehabilitation of Post Mining Areas: Mitigating The Ecological and Socio-Economic Impacts of Mining". Banjarbaru, 1516 September 2015.

Prihatini, N. S. (2015). "Performance of The Horizontal Subsurface-flow Constructed Wetland With Different Operational Procedures." International Journal of Advances in Engineering \& Technology7 (6): 1620-1629.

Prihatini, N. S. (2015). A Study of Iron (Fe) Uptake by Purun Tikus (Eleocharis dulcis) from Acid Mine Drainage in Subsurface Flow Constructed Wetland. International Conference: Natural, Mathematical and Environmental Sciences. Banjarbaru, Indonesia.

Risnawati, I. and T. P. Damanhuri (2010). "Metal removal in Leacheate using Constructed Wetland." Environmental Engineering 
Department, Faculty of Civil and Environmental Engineering, Institut Teknologi Bandung.

Samiotakis, M. and S. D. Ebbs (2004). "Possible evidence for transport of an iron cyanide complex by plants." Environmental Pollution127(2): 169-173.

Sobolewski, A. (1999). "A review of processes responsible for metal removal in wetlands treating contaminated mine drainage." International Journal of Phytoremediation1 (1): 19-51.

Solti, A., K. Kovács, et al. (2012). "Uptake and incorporation of iron in sugar beet chloroplasts." Plant Physiology and Biochemistry52(March): 91-97.

Vardanyan, L. G. and B. S. Ingole (2006). "Studies on heavy metal accumulation in aquatic macrophytes from Sevan (Armenia) and Carambolim (India) lake systems." Environment International32: 208-218.

Vile, M. A. and R. K. Wieder (1993). "Alkalinity generation by $\mathrm{Fe}(\mathrm{III})$ reduction versus sulfate reduction in wetlands constructed for acid mine drainage treatment." Water, Air, and Soil Pollution69(3-4): 425441.

Vymazal, J. (2003). Distribution of iron, cadmium, nickel and lead in a constructed wetland receiving municipal sewage. Wetlands Nutrients, Metals and Mass Cycling. J. E. Vymazal: 341-363.

Vymazal, J. (2005). "Removal of heavy metals in a horizontal sub-surface flow constructed wetland." Journal of Environmental Science and Health 40A: 1369-1379.

Wiessner, A., P. Kuschk, et al. (2006). "Effectiveness of Various SmallScale Constructed Wetland Designs for the Removal of Iron and Zinc from Acid Mine Drainage under Field Conditions." Engineering in Life Science6(6): 548-592.

Wood, T. S. and M. L. Shelley (1999). "A dynamic model of bioavailability of metals in constructed wetland sediments." Ecological
Yoshida, K. and T. Negishi (2013). "The identification of a vacuolar iron transporter involved in the blue coloration of cornflower petals." Phytochemistry94(Oct.): 60-67. 